\title{
Nutritional value of forage species from the Central Highlands Region of Mexico at different stages of maturity
}

\author{
Valor nutricional de espécies forrageiras nativas da Região Central Montanhosa do México em \\ diferentes estádios de maturidade
}

\author{
Adolfo Armando Rayas Amor ${ }^{\mathrm{I}}$ Julieta Gertrudis Estrada Flores ${ }^{\mathrm{II}}$ Fergus Lawrence Mould ${ }^{\mathrm{II}}$ \\ Octavio Alonso Castelán Ortega ${ }^{\mathrm{IV}}$
}

\begin{abstract}
This paper has two objectives, the first is to determine the chemical composition, gas production parameters and the gas release kinetics, at different stages of maturity, of three grasses and a legume commonly found in long established pastures in Mexico central highland plateau. The second is to combine the gas release kinetics analysis and the GP fitted to a mathematical model in order to improve the biological understanding of the fermentation kinetics obtained from the GP technique. Representative samples of Pennisetum clandestinum (kikuyu grass), Sporobolus indicus (mouse tail), Eleocharis dombeyana (reed), Trifolium amabile (Aztec clover) plus a composite sample were collected in the growing season (July, September and November 2003) and analysed using an in vitro gas production (GP) technique. The accumulated GP was fitted to the model described in PALMER et al. (2005). Significant differences $(P<0.001)$ were observed among species and periods for chemical composition, organic matter and neutral detergent fibre digestibility. Significant differences $(P<0.05)$ were observed regarding fermentation parameters and gas release kinetic, with T. amabile and P. clandestinum being the species with the highest fermentability, whereas $\boldsymbol{S}$. indicus and $\boldsymbol{E}$. dombeyana were poorly fermented. $\boldsymbol{P}$. clandestinum and T. amabile showed higher nutritive value than $\boldsymbol{S}$. indicus and $\boldsymbol{E}$. dombeyana. Composite samples were influenced by the chemical and fermentation characteristics of all species. It was concluded that the use of gas release kinetics analysis was useful for differentiating the fermentation kinetic of the soluble and insoluble fraction in the grasses and legume. Therefore by performing both approaches, the gas release kinetics analysis and the GP fitted to a mathematical model, gave a better description of the fermentation kinetic of grasses and the legume was achieved when only one approach had been used.
\end{abstract}

Key words: native pastures, fermentation parameters, gas release kinetic.

\section{RESUMO}

O uso da análise de cinética de produção de gases, em conjunto com a análise de prova de curva e as propriedades químicas da forragem permitem uma melhor descrição das características nutritivas das forragens. Objetivou-se estudar a composição nutritiva e características de fermentação de ruminal de três gramíneas, uma leguminosa e uma mistura composta de pastagens do Planalto Montanhoso Central do México. As amostras representativas de Pennisetum clandestinum (kikuyu grama), Sporobolus indicus (rabo de rato), Eleocharis dombeyana (cana), Trifolium amabile (trevo asteca) mais uma amostra composta foram coletadas durante os meses de Julho, Setembro e Novembro de 2003. Foi utilizada a técnica de produção de gás in vitro (GP). Os perfis de GP foram ajustados ao modelo descrito por PALMER et al. (2005). As diferenças $(P<0.001)$ foram observadas entre espécies $e$ períodos quanto à composição química, matéria orgânica $e$ digestibilidade da fibra em detergente neutro. As diferenças $(P<0.05)$ dos parâmetros de fermentação e cinética de produção de gases mostraram T. amabile e P. clandestinum com fermentação mais intensa, ao passo que $\boldsymbol{S}$. indicus $e \boldsymbol{E}$. dombeyana tiveram fermentação limitada. Concluiu-se que a combinação da análise de cinética de produção de gases e o perfil de GP ajustado ao modelo matemático ajudou a descrever as características nutritivas das gramíneas, da leguminosa e da amostra composta de forma mais acurada do que quando um dos métodos foi utilizado de forma isolada.

Palavras-chave: pastagens nativas, parâmetros de fermentação, cinética de produção de gases.

\footnotetext{
ICentro de Estudios Profesionales del Colegio Superior Agropecuario del estado de Guerrero (CEP-CSAEGRO), Cocula, Mexico. IIInstituto de Ciencias Agropecuarias y Rurales (ICAR), Universidad Autónoma del Estado de México (UAEM), Toluca, Mexico. IIIPrivate consultant, Scotland, United Kingdom.

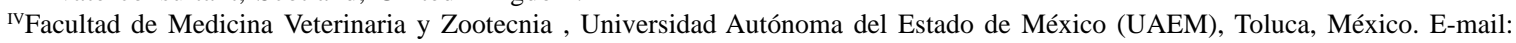
oaco2002@yahoo.com.mx. Autor para correspondência.
} 


\section{INTRODUCTION}

Currently the majority of forage research either in developed or developing countries has been devoted to the nutritional characterization of improved pastures, with little being done to study local and native species, despite of their importance, once most cattle in smallholder systems graze on these pastures. Current ruminant feeding systems (AFRC, 1993) require information on rumen degradation parameters in addition to the chemical composition of feedstuffs; however, in developing countries this information is scarce and unlikely to be either relevant or applicable to local production systems (JUAREZ et al., 2009). Rumen degradation kinetics and nutritional characteristics of tropical climate forages are not available in tables of current feeding systems because they mainly contain information from temperate climate forages. However, there are important differences between forages from the tropics and those from temperate climates. Therefore there is the need to generate information on the fermentation kinetics and nutritional characteristics of forage plants from the warmer regions of the world, so they can be used with the current feeding systems. On the other hand, there are many papers on in vitro gas production studies focused only on fitting the GP data to a curvilinear model in order to give a mathematical explanation of a biological process (FRANCE et al., 1993), but very few researchers analyse the gas release kinetics and its biological meaning. The analysis of the gas release kinetics allows differentiating more clearly the amount of gas released from the soluble and the insoluble fractions and its fermentation over time (MOULD et al., 2005). Therefore the present paper has two objectives, the first is to determine the chemical composition, gas production parameters and the gas release kinetics, at different stages of maturity, of three grasses and a legume commonly found in long established pastures in the central highland plateau of Mexico. The second objective is to combine the gas release kinetics analysis and the GP fitted to a mathematical model in order to improve the biological understanding of the of the fermentation kinetics obtained from the GP technique.

\section{MATERIALS AND METHODS}

The studied native pastures plots are situated in the Toluca valley in the central highlands of Mexico $\left(19^{\circ} 27^{\prime} \mathrm{N}\right.$ and $99^{\circ} 38^{\prime} \mathrm{W}$ ) at an altitude of $2650 \mathrm{~m}$. During the study period $890 \mathrm{~mm}$ rain was recorded and the temperature ranged from 5 to $25^{\circ} \mathrm{C}$. Samples of Pennisetum clandestinum, Sporobolus indicus,
Trifolium amabile, Eleocharis dombeyana and composite samples, which included all species harvested, were recollected from trial sites continuously grazed by cattle over the year. The trial sites are known as communal pastures since all farmers who are settled in the community can make use of those pastures. In this study, four different trial sites were sampled, each trial site had four plots of 0.5 ha, therefore sixteen noncultivated pasture plots were sampled in three periods. Samples collection: Three harvest periods were established for sample collection; July (P1), September (P2) and November (P3) of 2003. All plants within a $0.250 \mathrm{~m}^{2}$ quadrant were cut with shears at ground level for each sampling point in a "W" pattern. All plants were harvested within one week in each period. The quadrant was thrown five times in each plot and marked with pegs in order to ensure that the same "point" was sampled each period, therefore sixteen plots, five replications and three periods gave a total of 240 samples collected.

Samples preparation: The fresh weight of each harvested sample was immediately recorded and then the samples were placed in plastic bags for later drying. In the laboratory samples' weight was recorded after drying at $60^{\circ} \mathrm{C}$ until constant weight. Samples were milled with a hammer mill to pass a $1 \mathrm{~mm}$ sieve and then they were stored at room temperature for chemical and in vitro fermentation analyses.

Dry matter availability (DMa): the DMa was determined by multiplying the fresh weight of plants harvested within the $0.250 \mathrm{~m}^{2}$ quadrant by their dry matter content. Species proportion determination: All plants within a $0.250 \mathrm{~m}^{2}$ quadrant were cut with shears at ground level at the same day and in the immediate vicinity of the quadrant used for harvesting samples that were analyzed for chemical composition and then the fresh weight was recorded after cutting (GRANT, 1981). The proportion of species was determined by separating the harvested material into grasses, legumes and weeds. After separation, the dry matter (DM) content of each species was obtained by drying at $100^{\circ} \mathrm{C}$ until constant weight. These samples were not used in the chemical composition and in vitro fermentation analyses.

Chemical Analyses: Samples were analysed for DM content (AOAC, 1990; ID 950.01), ash content by burning the samples at $550^{\circ} \mathrm{C}$ during $3 \mathrm{~h}$ in a furnace oven (AOAC, 1990; ID 942.05) and organic matter content (OM) by difference between DM and ash content. Nitrogen $(\mathrm{N})$ was estimated using the Kjeldahl method with crude protein expressed as Nx6.25 (AOAC, 1990; ID 954.01). Neutral detergent fibre (NDF), acid detergent fibre (ADF) and acid detergent lignin (ADL) were estimated according to VAN SOEST et al. (1991), 
sodium sulphite was used in the detergent solution. NDF, ADF and ADL were determined sequentially from the same subsample and express inclusive residual ash. Hemicellulose was calculated as NDF minus ADF, and cellulose as the difference between ADF and ADL. In vitro gas production (GP) analyses: The Reading Pressure Technique described in MAURICIO et al. (1999) was used. Rumen liquor was collected and mixed just before the morning feeding, from two fistulated steers, which were offered a diet comprising alfalfa hay, oat stover and commercial concentrate twice a day. Approximately $1 \mathrm{~g}$ (milled to pass $1 \mathrm{~mm}$ screen) sample was weighed into pre-washed (distilled water) $160 \mathrm{ml}$ serum flasks. Reduced buffer $(90 \mathrm{ml})$ medium (THEODOROU et al., 1994) was added to each flask using an automatic dispenser (Jencons, Hemel Hempstead, UK) then the flasks were closed with butyl rubber stoppers and stored overnight at $4^{\circ} \mathrm{C}$. Prior to inoculation with rumen liquor, the flasks were warmed to $39^{\circ} \mathrm{C}$ and flushed with $\mathrm{CO}_{2}$. Each flask was then inoculated with $10 \mathrm{ml}$ prepared inoculum and then sealed with the rubber stoppers. The flasks were then shaken and placed in a water bath at $39^{\circ} \mathrm{C}$. All fermentations were conducted in triplicate per sample in one run. Accumulated head-space gas pressure was measured using a pressure transducer (Type TP 804, Delta OHM, Italy) connected to a microprocessor pressure gauge at hourly intervals during the first $8 \mathrm{~h}$, then after 12, 16, $20,24,28,36,44,52,60,72,96$ and 120 h of incubation. Accumulated gas was released following each measurement. Pressure readings were converted to volume using a linear regression derived in the laboratory. A $20 \mathrm{ml}$ plastic syringe was used to inject increasing volumes of air into an empty $160 \mathrm{ml}$ serum flask, afterwards the pressure within the bottle was measured with the pressure transducer. Ninety-five readings were recorded per day and this process was repeated for two more days, so a total of 285 readings were used to derive the equation below.

Volume $(\mathrm{ml})=($ PSI -0.1056$) * 3.3378\left(r^{2}=0.99\right)$

Accumulated gas production fitting: mean volumes for each treatment of cumulative gas production were fitted to the model described in PALMER et al. (2005): $\boldsymbol{y}=\boldsymbol{a}(1-\exp (-\boldsymbol{c} \mathbf{t}))+\boldsymbol{b}(1-\exp (-\boldsymbol{c} 2(\mathrm{t}-\mathbf{l a g}))) \times \exp (5(\mathrm{t}-\mathbf{l a g})) /$ $(1+\exp (5(\mathrm{t}-\mathbf{l a g})))$ where, $\boldsymbol{y}$ represents the cumulative gas production, $\boldsymbol{a}$ gas produced from quickly degraded carbohydrates $(\mathrm{ml}), \boldsymbol{c} \mathbf{1}$ the fractional rate of gas produced from $\boldsymbol{a}$ fraction $\left(\mathrm{h}^{-1}\right), \boldsymbol{t}$ incubation time (h), $\boldsymbol{b}$ gas produced from insoluble fraction $(\mathrm{ml}), \boldsymbol{c} \mathbf{2}$ the fractional rate of gas produced from $\boldsymbol{b}$ fraction $\left(\mathrm{h}^{-1}\right)$ and Iag is the discrete $\mathbf{l a g}$ time (h) before fermentation of insoluble fraction begins.

Potential apparent digestibility of NDF (PDNDF): it was estimated by recovering the residual neutral detergent fibre (RNDF) from the in vitro gas production immediately after $120 \mathrm{~h}$ of incubation. Residues were autoclaved with $60 \mathrm{ml}$ of neutral detergent solution for one hour at $105^{\circ} \mathrm{C}$, afterwards they were filtered through crucibles (pore size 1 ), rinsed with boiling water and then dried to constant weight overnight at $60^{\circ} \mathrm{C}$ (PELL \& SCHOFIELD, 1993). The PDNDF was calculated with the formula: PDNDF( $\left.\mathrm{g} \mathrm{kg}^{-1} \mathrm{NDF}\right)$ $=((\mathrm{NDF}-\mathrm{RNDF}) / \mathrm{NDF}) * 100$. Where NDF is the initial concentration of neutral detergent fibre in the forage sample.

Potential apparent digestibility of OM (PDOM): it was estimated by recovering the residual organic matter and then drying the residue at $100^{\circ} \mathrm{C}$ for $24 \mathrm{~h}$. The residual ash was obtained by burning the sample at $550^{\circ} \mathrm{C}$ and then the PDOM was estimated by the difference between residual DM, residual ash and the initial OM content of the forage sample. In addition four bottles containing standard maize straw (feed reference) were also incubated per run.

Estimation of in vitro gas release kinetics: The accumulated head-space gas volume in each measurement time was divided by the incubation time i.e. by 1 during the first $8 \mathrm{~h}$ of incubation, then by 4 until $28 \mathrm{~h}$ of incubation, then by 8 until $60 \mathrm{~h}$ of incubation, then by 12 until $96 \mathrm{~h}$ and the last measurement by $24 \mathrm{~h}$ (MOULD et al., 2000; MOULD et al., 2005).

Statistical Analysis of data: To examine differences between trial sites $(C)$, species $(S)$, periods $(P)$, and the interaction $S x P$, a split plot design was used, with $S$ as the main plot with four levels (1= composite sample, $2=$ P. calndestinum, $3=S$. indicus, $4=E$. dombeyana), $P$ as the split plot with three levels $(1=\mathrm{P} 1,2=\mathrm{P} 2,3=\mathrm{P} 3)$ and $C$ as blocking factor with four levels $(1=\mathrm{C} 1,2=\mathrm{C} 2$, $3=\mathrm{C} 3,4=\mathrm{C} 4)$. The model used is of the form: $\mathrm{Y}_{\mathrm{ijk}}=i+C_{i}$ $+\mathrm{S}_{j}+\ddot{a}_{i j}+P_{k}+\left(S^{*} P\right)+e_{i j k}$, where $\mathbf{i}=$ is the overall mean, $\boldsymbol{C}_{\boldsymbol{i}}=$ is the th random block effect $(i=1,2,3,4), \boldsymbol{S} \boldsymbol{j}=$ is the ${ }_{j}$ th main plot treatment effect $(j=1,2,3,4), \ddot{a} i j=$ is the ${ }_{i j}$ th random main plot error effect, $\boldsymbol{P} \boldsymbol{k}=$ is the ${ }_{k}$ th split plot treatment effect $(k=1,2,3),(\boldsymbol{S} \boldsymbol{j} \boldsymbol{P} \boldsymbol{k})=$ is the $_{j k}$ th interaction of the main plot and the split plot and eijk $=$ is the ${ }_{k}$ th random split plot error effect. The GLM command of MINITAB (2000) was used.

\section{RESULTS AND DISCUSION}

Dry matter availability and proportion of species: there were significant differences $(\mathrm{P}<0.01)$ in $\mathrm{DMa}$ of composite samples by period and the interaction SxP, showing a decline in P1 (2.1 $\left.\mathrm{t}^{-1} \mathrm{ha}\right)$, followed by P2 (1.4 $\left.\mathrm{t}^{-1} \mathrm{ha}\right)$ and finally P3 (0.8 $\left.\mathrm{t}^{-1} \mathrm{ha}\right)$. Penisetum clandestinum had the highest proportion $(\mathrm{P} 1=0.75 ; \mathrm{P} 2=0.79$; $\mathrm{P} 3=0.44$ ), followed by T. amabile (P1=0.18; $\mathrm{P} 2=0.13$; $\mathrm{P} 3=0.03$ ) and the lowest proportion was observed in $\boldsymbol{S}$. indicus 
(P1 and P2=0.01; P3=0.05). The proportion in $\boldsymbol{E}$. dombeyana and weeds increased from $\mathrm{P} 1$ to $\mathrm{P} 3$ $(\mathrm{P} 1=0.02 ; \mathrm{P} 2=0.05 ; \mathrm{P} 3=0.11$ and $\mathrm{P} 1=0.04 ; \mathrm{P} 2=0.02$; $\mathrm{P}=$ 0.37 , respectively). The rise in the proportion of $S$. indicus, E. dombeyana and weeds in P3 was likely due to their lower palatability than the other species.

Chemical composition: Results of the chemical composition are shown in table 1 . Significant differences $(\mathrm{P}<0.01)$ among trial sites, species, periods and the $\mathrm{S} \mathrm{x}$ $\mathrm{P}$ interaction were observed for these variables. As expected, the highest CP content was observed in $\mathbf{T}$. amabile but $\boldsymbol{P}$. clandestinum and $\boldsymbol{E}$. dombeyana also showed a high CP content; even more than composite sample. The CP content declined from P1 to P3. Sporobolus indicus not only had the highest DM content from P1 to P3 but also had the highest NDF and ADF content. Note that ADL declined from P2 to P3 in all species and the composite sample, being less marked in T. amabile and $\boldsymbol{E}$. dombeyana. This suggest that decline in quality of studied species is not as fast as in other species.
Hemicellulose, cellulose, ME, PDOM and PDNDF are shown in table 2. Significant differences $(\mathrm{P}<0.001)$ were observed for these variables in species only. The highest contents of hemicellulose were observed in $\boldsymbol{S}$. indicus and P.clandestinum, whereas $\boldsymbol{S}$. indicus and E.dombeyana showed the highest cellulose content, suggesting that these species are important source of energy for microbes (BONDI, 1987), because forage breakdown and thus energy release is dependent upon fermentation rate and PDNDF. The high ADF and lignin contents are related to low PDNDF since lignin limits the accessibility to rumen microbes, although this relationship is complex and highly variable WALLACE et al. (2001). Although legumes have higher lignin content than grasses its PDOM and PDNDF in $\boldsymbol{T}$. Amabile were not the lowest. The explanation might be that only one tissue type in the stem or leaf of legumes is affected by lignin (WILSON et al., 1991).

In vitro gas production: GP parameters derived from the model are shown in table 3 . Significant differences $(\mathrm{P}<0.001)$ were observed in species and periods for $\boldsymbol{a}$,

Table 1 - Chemical composition ( $\mathrm{g} \mathrm{kg}^{-1} \mathrm{DM}$ ) of native species

\begin{tabular}{|c|c|c|c|c|c|c|c|}
\hline NI & Period & $\mathrm{DM} \mathrm{g} \mathrm{kg}^{-1}$ & $\mathrm{CP}$ & $\mathrm{OM}$ & NDF & $\mathrm{ADF}$ & $\mathrm{ADL}$ \\
\hline \multirow[t]{3}{*}{ Composite sample } & 1 & $230^{\mathrm{aa}}$ & $124^{\text {a }}$ & $895^{\mathrm{ab}}$ & $591^{\text {a a }}$ & $284^{\text {a }}$ & $44^{\mathrm{aa}}$ \\
\hline & 2 & $300^{\mathrm{ab}}$ & $123^{\mathrm{a} b}$ & $901^{\mathrm{ab}}$ & $673^{\mathrm{ab}}$ & $340^{\mathrm{a} b}$ & $77^{\mathrm{a} b}$ \\
\hline & 3 & $472^{\mathrm{ac}}$ & $72^{\mathrm{ac}}$ & $897^{\mathrm{a} b}$ & $659^{a c}$ & $340^{\mathrm{ac}}$ & $64^{\mathrm{ac}}$ \\
\hline \multirow[t]{3}{*}{ P. clandestinum } & 1 & $185^{\mathrm{ba}}$ & $157^{\mathrm{ba}}$ & $875^{\mathrm{ba}}$ & $632^{\mathrm{aa}}$ & $272^{\mathrm{aa}}$ & $36^{\text {a a }}$ \\
\hline & 2 & $197^{\mathrm{bb}}$ & $147^{\mathrm{bb}}$ & $880^{a \mathrm{a}}$ & $654^{\mathrm{a} b}$ & $318^{\mathrm{a} b}$ & $61^{\mathrm{a} \mathrm{b}}$ \\
\hline & 3 & $346^{\mathrm{bc}}$ & $88^{a c}$ & $891^{\text {a }}$ & $644^{\mathrm{ac}}$ & $292^{\mathrm{bc}}$ & $46^{\mathrm{ac}}$ \\
\hline \multirow[t]{3}{*}{ S. indicus } & 1 & $316^{\mathrm{ca}}$ & $94^{\mathrm{ca}}$ & $938^{\mathrm{ca}}$ & $722^{\mathrm{ba}}$ & $324^{\mathrm{ba}}$ & $40^{\text {ba }}$ \\
\hline & 2 & $423^{c b}$ & $63^{\mathrm{cb}}$ & $917^{\mathrm{a} a}$ & $754^{\mathrm{bb}}$ & $384^{\mathrm{a} b}$ & $70^{\mathrm{ab}}$ \\
\hline & 3 & $759^{c c}$ & $39^{\mathrm{bc}}$ & $927^{\mathrm{a} a}$ & $774^{\mathrm{bc}}$ & $400^{c c}$ & $55^{\mathrm{ac}}$ \\
\hline \multirow[t]{3}{*}{ E. dombeyana } & 1 & $249^{\mathrm{a} a}$ & $149^{\mathrm{ba}}$ & $879^{\text {ba }}$ & $595^{\mathrm{a} a}$ & $304^{\text {a a }}$ & $44^{\mathrm{a} a}$ \\
\hline & 2 & $274^{\mathrm{a} b}$ & $128^{\mathrm{ab}}$ & $881^{\text {a a }}$ & $665^{\mathrm{a} b}$ & $373^{\mathrm{a} b}$ & $92^{\mathrm{a} b}$ \\
\hline & 3 & $449^{d c}$ & $97^{\mathrm{bc}}$ & $878^{\mathrm{a} a}$ & $635^{a c}$ & $367^{\mathrm{ac}}$ & $84^{\mathrm{bc}}$ \\
\hline \multirow[t]{3}{*}{ T. amabile ${ }^{\dagger}$} & 1 & $207^{\mathrm{a}}$ & $204^{\mathrm{a}}$ & $890^{a}$ & $451^{\mathrm{a}}$ & $275^{\mathrm{a}}$ & $70^{a}$ \\
\hline & 2 & $365^{\mathrm{b}}$ & $175^{\mathrm{b}}$ & $909^{\text {a }}$ & $488^{b}$ & $301^{\mathrm{b}}$ & $92^{\mathrm{b}}$ \\
\hline & 3 & $497^{\mathrm{c}}$ & $170^{\mathrm{b}}$ & $905^{\mathrm{a}}$ & $491^{\mathrm{c}}$ & $303^{b}$ & $94^{\mathrm{b}}$ \\
\hline s. e. m. & & 23.1 & 5.6 & 3.2 & 8.5 & 6.5 & 3.1 \\
\hline \multicolumn{8}{|l|}{ Significance for: } \\
\hline Trial sites (C) & & NS & NS & $* * *$ & $* *$ & $* * *$ & $* *$ \\
\hline Species (S) & & $* * *$ & $* * *$ & $* * *$ & $* * *$ & $* * *$ & $* * *$ \\
\hline Period (P) & & $* * *$ & $* * *$ & NS & $* * *$ & $* * *$ & $* * *$ \\
\hline $\mathrm{S} \times \mathrm{P}$ & & $* * *$ & $* *$ & $* *$ & $* *$ & NS & NS \\
\hline
\end{tabular}

DM, dry matter; CP, crude protein; OM, organic matter; NDF, neutral detergent fibre; ADF, acid detergent fibre; ADL, acid detergent lignin; NS, not significant; $* \mathrm{P}<0.05 ; * * \mathrm{P}<0.01 ; * * * \mathrm{P}<0.001$. ${ }^{\dagger}$ Not statistically compared among species. Mean values within columns with different superscript differ significantly $(\mathrm{P}<0.05)$. First column of superscripts represent comparisons of means among species. Second column of superscripts represent comparisons of means among periods. 
Table 2 - Hemicellulose ( $\mathrm{g} \mathrm{kg}^{-1} \mathrm{NDF}$ ), cellulose ( $\mathrm{g} \mathrm{kg}^{-1} \mathrm{ADF}$ ), apparent organic matter digestibility $\left(\mathrm{g} \mathrm{kg}^{-1} \mathrm{OM}\right.$ ), neutral-detergent fibre digestibility $\left(\mathrm{g} \mathrm{kg}^{-1} \mathrm{NDF}\right)$ of native grass species $(\mathrm{n}=16)$ by periods $(\mathrm{n}=80)$.

\begin{tabular}{|c|c|c|c|c|c|}
\hline Species & Period & Hemicellulose & Cellulose & PDOM & PDNDF \\
\hline \multirow[t]{3}{*}{ Composite sample } & 1 & $307^{\text {a a }}$ & $240^{\text {a a }}$ & $721^{\text {a a }}$ & $469^{\text {a a }}$ \\
\hline & 2 & $333^{\mathrm{ab}}$ & $263^{a b}$ & $611^{\mathrm{ab}}$ & $407^{\mathrm{ab}}$ \\
\hline & 3 & $319^{\mathrm{a} b}$ & $277^{\mathrm{a}^{\mathrm{b}}}$ & $600^{\mathrm{ab}}$ & $342^{\mathrm{ac}}$ \\
\hline \multirow[t]{3}{*}{ P. clandestinum } & 1 & $361^{\text {a a }}$ & $236^{\mathrm{a} a}$ & $730^{\text {ba }}$ & $546^{\mathrm{ba}}$ \\
\hline & 2 & $336^{\text {a a }}$ & $257^{\text {b b }}$ & $646^{\mathrm{ab}}$ & $447^{\mathrm{bb}}$ \\
\hline & 3 & $351^{\text {a a }}$ & $246^{\text {a a }}$ & $568^{\mathrm{a} \mathrm{c}}$ & $402^{\mathrm{bb}}$ \\
\hline \multirow[t]{3}{*}{ S. indicus } & 1 & $399^{\text {ba }}$ & $284^{\text {ba }}$ & $745^{\text {ba }}$ & $609^{\mathrm{a} a}$ \\
\hline & 2 & $370^{\mathrm{bb}}$ & $314^{\mathrm{ab}}$ & $548^{\mathrm{bb}}$ & $444^{\mathrm{cb}}$ \\
\hline & 3 & $375^{\mathrm{bb}}$ & $344^{a^{c}}$ & $582^{\mathrm{bb}}$ & $445^{c b}$ \\
\hline \multirow[t]{3}{*}{ E. dombeyana } & 1 & $291^{\text {ca }}$ & $260^{\text {ba }}$ & $664^{\mathrm{ca}}$ & $478^{\mathrm{ba}}$ \\
\hline & 2 & $292^{\mathrm{ca}}$ & $281^{b c}$ & $550^{\mathrm{ab}}$ & $367^{d b}$ \\
\hline & 3 & $268^{\mathrm{cb}}$ & $283^{\mathrm{bb}}$ & $476^{\text {a c }}$ & $230^{\mathrm{bb}}$ \\
\hline \multirow[t]{3}{*}{ T. amabile $^{\dagger}$} & 1 & $177^{\mathrm{a}}$ & $204^{\mathrm{a}}$ & $701^{\mathrm{a}}$ & $340^{a}$ \\
\hline & 2 & $186^{\mathrm{b}}$ & $210^{b}$ & $656^{\mathrm{b}}$ & $278^{b}$ \\
\hline & 3 & $185^{\mathrm{b}}$ & $208^{b}$ & $654^{\mathrm{b}}$ & $276^{b}$ \\
\hline s. e. m. & & 6 & 4.8 & 12.9 & 14.5 \\
\hline Trial sites (C) & & $*$ & $* *$ & NS & NS \\
\hline Species (S) & & $* * *$ & $* * *$ & $* * *$ & $* * *$ \\
\hline Period (P) & & $*$ & $* * *$ & $* * *$ & $* * *$ \\
\hline $\mathrm{S} \times \mathrm{P}$ & & $* *$ & $* *$ & NS & $*$ \\
\hline
\end{tabular}

PDOM, apparent digestibility of organic matter; PDNDF, apparent digestibility of neutral-detergent fibre; NS, not significant; *P $<0.05$; $* * \mathrm{P}<0.01 ; * * * \mathrm{P}<0.001 ;{ }^{\dagger}$ Not statistically compared among species. Mean values within columns with different superscript differ significantly $(\mathrm{P}<0.05)$. First column of superscripts represent comparisons of means among species. Second column of superscripts represent comparisons of means among periods.

$\boldsymbol{b}, \boldsymbol{c} 2$ and $\mathbf{l a g}$. Only the S x P interaction for $\boldsymbol{b}$ and $\mathbf{l a g}$ were significant $(\mathrm{P}<0.05)$. These differences were expected because of the significant differences observed in NDF and PDNDF contents. GETACHEW et al. (2004) mentioned that the fibre composition of a feed determines its rate of fermentation through its direct effect on microbial activity. The highest gas volume released from soluble fraction (a) was observed in $\boldsymbol{T}$. amabile, $\boldsymbol{S}$. indicus and composite sample in P1 respectively, therefore they showed the highest $\boldsymbol{c 1}$ in the same period. However, note that $\boldsymbol{c 1}$ in $\boldsymbol{S}$. indicus declines in P2 and P3. The highest gas release from $\boldsymbol{b}$ fraction occurred in $\boldsymbol{S}$. indicus (P1) and $\boldsymbol{P}$. clandestinum (P2 and P3) although $\boldsymbol{S}$. indicus had higher lag time in P2 and P3. P. clandestinum had the highest cumulative gas volumes due to a high hemicellulose content and low cellulose and ADL content. This can be explained because hemicellulose is the NDF fraction that is entirely fermented by micro-organisms (VAN SOEST, 1991) (Figure 1A). This is in line with MERTENS (2005) who mentioned that the degradation of forages is primarily determined by the properties of the cell wall and secondly by the concentration of cell components.
Gas release kinetics: CHESSON (1990) described how fermentation of cell wall components involves a fully degradable primary cell wall fraction, a more slowly degraded cell wall fraction and fraction that is effectively resistant to fermentation during the normal time span that material remains in the rumen. (Figures 1A) and b) follow this pattern since the maximum fermentation of non structural carbohydrates might be represented by the peak at $8 \mathrm{~h}$ and fermentation of insoluble fraction by the peak at $16 \mathrm{~h}$ onwards. This approach explores the gas released per hour from the non structural carbohydrates and that one released from the insoluble fraction. This fermentation patterns are missed when data are fitted only to the mathematical model (PALMER et al., 2005).

Significant differences $(\mathrm{P}<0.001)$ were observed for species and periods at 8 and $16 \mathrm{~h}$ post incubation. T. amabile showed the highest gas released in all harvest periods at both 8 and 16h whereas the lowest was observed in $\boldsymbol{S}$. indicus and $\boldsymbol{E}$. dombeyana at the same hours (Table 3 and Figure 1A). Following the gas release kinetic approach, (Figure 1A) suggest that non structural carbohydrates contents were higher 
Table 3 - Gas production parameters and gas release kinetics by species and harvest periods ( $\mathrm{n}=16)$. Values in $\mathrm{ml}^{-1} \mathrm{DM}$ unless otherwise stated

\begin{tabular}{|c|c|c|c|c|c|c|c|c|}
\hline \multirow{2}{*}{ Species } & \multirow{2}{*}{ Period } & \multicolumn{5}{|c|}{-----------------------------GP parameters------------------------------ } & \multicolumn{2}{|c|}{----Gas release kinetics---- } \\
\hline & & $a$ & $c 1\left(\mathrm{~h}^{-1}\right)$ & $b$ & $c 2\left(\mathrm{~h}^{-1}\right)$ & $\operatorname{Lag}(\mathrm{h})$ & $8\left(h^{-1}\right)$ & $16\left(\mathrm{~h}^{-1}\right)$ \\
\hline \multirow[t]{3}{*}{ Composite sample } & 1 & $23^{\mathrm{a}}$ & $0.21^{\mathrm{a}}$ & $232^{\text {a a }}$ & $0.040^{\text {a a }}$ & $4^{\mathrm{aa}}$ & $7.7^{\mathrm{aa}}$ & $7.3^{\mathrm{a} a}$ \\
\hline & 2 & $14^{\mathrm{b}}$ & $0.15^{\mathrm{a}}$ & $196^{\mathrm{ab}}$ & $0.031^{\mathrm{ab}}$ & $6^{\mathrm{ab}}$ & $3.4^{\mathrm{ab}}$ & $5.4^{\mathrm{ab}}$ \\
\hline & 3 & $13^{\mathrm{b}}$ & $0.09^{\mathrm{b}}$ & $183^{\mathrm{ac}}$ & $0.031^{\mathrm{ab}}$ & $6^{\mathrm{ab}}$ & $4.1^{\mathrm{ab}}$ & $4.2^{\mathrm{ac}}$ \\
\hline \multirow[t]{3}{*}{ P. clandestinum } & 1 & $19^{\mathrm{a}}$ & $0.21^{\mathrm{a}}$ & $231^{\text {a a }}$ & $0.040^{\mathrm{a} a}$ & $6^{\text {ba }}$ & $6.3^{\mathrm{ba}}$ & $7.8^{\text {a a }}$ \\
\hline & 2 & $11^{\mathrm{b}}$ & $0.14^{\mathrm{a}}$ & $206^{\mathrm{ab}}$ & $0.037^{\mathrm{b} b}$ & $6^{\mathrm{aa}}$ & $3.8^{\mathrm{ab}}$ & $6.1^{\mathrm{ab}}$ \\
\hline & 3 & $19^{\mathrm{a}}$ & $0.11^{\mathrm{b}}$ & $210^{\mathrm{bb}}$ & $0.037^{\mathrm{bb}}$ & $6^{\mathrm{aa}}$ & $6.5^{\mathrm{ba}}$ & $5.7^{\mathrm{bb}}$ \\
\hline \multirow[t]{3}{*}{ S. indicus } & 1 & $21^{\mathrm{a}}$ & $0.22^{\mathrm{a}}$ & $247^{\text {a a }}$ & $0.037^{\mathrm{ba}}$ & $6^{\mathrm{ba}}$ & $5.9^{\mathrm{a} a}$ & $7.7^{\mathrm{aa}}$ \\
\hline & 2 & $18^{\mathrm{c}}$ & $0.10^{\mathrm{b}}$ & $184^{\mathrm{ab}}$ & $0.029^{\mathrm{b} b}$ & $9^{\mathrm{bb}}$ & $1.7^{\mathrm{bb}}$ & $4.1^{\mathrm{ab}}$ \\
\hline & 3 & $17^{\mathrm{a}}$ & $0.12^{\mathrm{b}}$ & $193^{\mathrm{a} b}$ & $0.025^{c c}$ & $11^{\mathrm{bc}}$ & $1.7^{\mathrm{cb}}$ & $3.0^{\mathrm{ac}}$ \\
\hline \multirow[t]{3}{*}{ E. dombeyana } & 1 & $19^{\mathrm{a}}$ & $0.19^{\mathrm{a}}$ & $215^{\text {a a }}$ & $0.037^{\mathrm{ba}}$ & $5^{\mathrm{ba}}$ & $5.2^{\mathrm{aa}}$ & $7.1^{\mathrm{a} \mathrm{a}}$ \\
\hline & 2 & $11^{\mathrm{b}}$ & $0.16^{\mathrm{a}}$ & $159^{\mathrm{ab}}$ & $0.031^{\mathrm{ab}}$ & $6^{\mathrm{ab}}$ & $2.9^{\mathrm{ab}}$ & $3.9^{\mathrm{ab}}$ \\
\hline & 3 & $15^{\mathrm{b}}$ & $0.12^{\mathrm{b}}$ & $132^{\mathrm{cc}}$ & $0.030^{\mathrm{ab}}$ & $6^{\mathrm{ab}}$ & $2.8^{\mathrm{ab}}$ & $2.5^{\mathrm{cc}}$ \\
\hline \multirow[t]{3}{*}{ T. amabile ${ }^{\dagger}$} & 1 & $28^{\mathrm{a}}$ & $0.24^{\mathrm{a}}$ & $211^{\mathrm{a}}$ & $0.054^{\mathrm{a}}$ & $4^{\mathrm{a}}$ & $10.2^{\mathrm{a}}$ & $8.3^{\mathrm{a}}$ \\
\hline & 2 & $25^{\mathrm{a}}$ & $0.20^{\mathrm{b}}$ & $195^{\mathrm{b}}$ & $0.047^{\mathrm{b}}$ & $4^{\mathrm{a}}$ & $8.8^{\mathrm{b}}$ & $7.2^{\mathrm{b}}$ \\
\hline & 3 & $23^{b}$ & $0.20^{\mathrm{b}}$ & $190^{c}$ & $0.045^{\mathrm{b}}$ & $4^{\mathrm{a}}$ & $8.7^{\mathrm{b}}$ & $7.1^{\mathrm{b}}$ \\
\hline s. e. m. & & 0.72 & 0.008 & 5.2 & 0.001 & 0.4 & 0.3 & 0.3 \\
\hline Trial sites (C) & & NS & NS & NS & NS & NS & $* * *$ & $*$ \\
\hline Species (S) & & $*$ & NS & $* * *$ & $* * *$ & $* * *$ & $* * *$ & $* * *$ \\
\hline Period (P) & & NS & $*$ & $* * *$ & $* * *$ & $* * *$ & $* * *$ & $* * *$ \\
\hline $\mathrm{S} \times \mathrm{P}$ & & NS & NS & $*$ & NS & $*$ & $* * *$ & $* * *$ \\
\hline
\end{tabular}

$\boldsymbol{a}$, Gas produced from quickly degradable carbohydrates; $\boldsymbol{c 1}$, rate of gas produced from quickly degradable carbohydrates; $\boldsymbol{b}$, gas produced from insoluble fraction; $\boldsymbol{c}$, rate of gas produced from insoluble fraction; $\mathbf{l a g}$, time (h) before fermentation of insoluble fraction begins.

NS, not significant; $* \mathrm{P}<0.05 ; * * * \mathrm{P}<0.001{ }^{\dagger}{ }^{\dagger}$ Not statistically compared among species. Mean values within columns with different superscript differ significantly $(\mathrm{P}<0.05)$. First column of superscripts represent comparisons of means among species. Second column of superscripts represent comparisons of means among periods.

in T. amabile than in the other species. According to HETTA (2004) legumes are high in soluble and peptic substances therefore their substrate is readily available for microbes. The NDF content in T. amabile was lower than in the other species (Table 1) and showed the highest gas release kinetic at $16 \mathrm{~h}$ followed by a sharp drop after this hour (Figure 1A). On the other hand, $\boldsymbol{S}$. indicus showed the highest gas release kinetics after 28 h, due to its high cellulose content, but $\boldsymbol{c} 2$ in $\boldsymbol{S}$. indicus is low probably because the low fermentability as crystallinity affects hemicellulose and cellulose (MERTENS, 2005; JUNG \& DEETZ, 1993).

(Figure 1B) shows the gas release kinetics for composite samples in different harvest periods. Only significant differences $(\mathrm{P}<0.05)$ were observed after $36 \mathrm{~h}$ post inoculation. It can be observed that $\mathrm{P} 1$ had two well defined peaks at 8 and $16 \mathrm{~h}(\mathrm{P}>0.05)$, whereas the peak at $8 \mathrm{~h}$ is less marked in $\mathrm{P} 2$ and $\mathrm{P} 3(\mathrm{P}<0.05)$. Results in (Figure 1B) show that fermentation of insoluble fraction declined in $\mathrm{P} 2$ and $\mathrm{P} 3$ due to the increment of ADF content in the same periods (Table 1). According to GUSTAVSSON \& MARTINSSON (2004) when the insoluble fibre concentration increases, impacts negatively on fermentation. This explains the low fermentation in the last two periods (P2 and P3) and in the species showing low fermentation.

\section{CONCLUSION}

P. clandestinum and T. amabile showed higher nutritive value than $\boldsymbol{S}$. indicus and $\boldsymbol{E}$. dombeyana. Composite samples were influenced by the chemical and fermentation characteristics of all species. The use of gas release kinetics analysis permitted a better description of the fermentation characteristics of the soluble and insoluble fraction in 


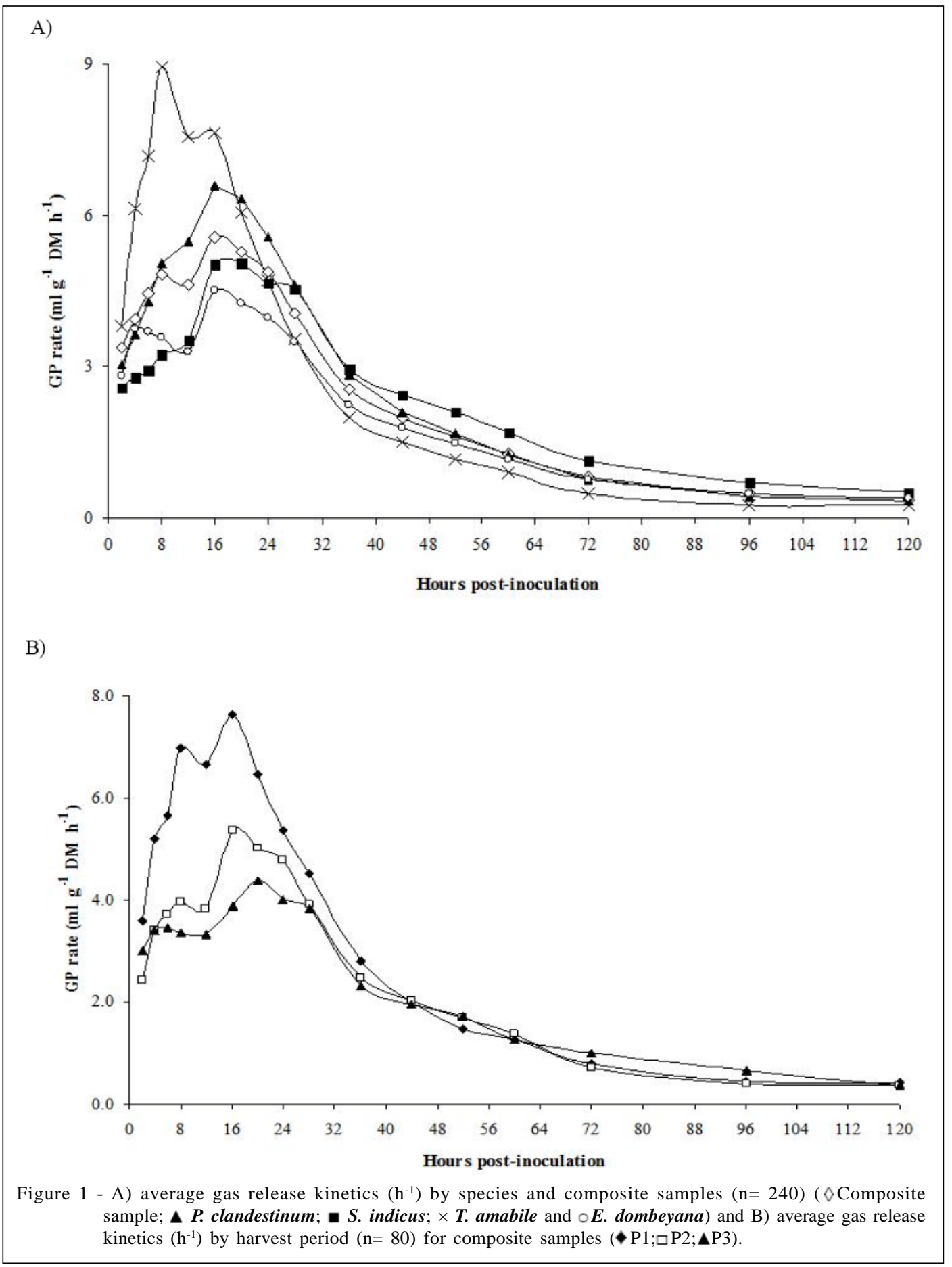

the grasses and the legume than the curve fitting analysis alone. Therefore by performing both approaches, the gas release kinetics analysis and the GP fitted to a mathematical model, a better description of the fermentation kinetic of the grasses and the legume was achieved if only one approach had been used.

\section{ACKNOWLEDGMENTS}

This research was founded by the Universidad Autónoma del Estado de México, grant 2344/2006 and the Instituto de Investigación y Capacitación Agropecuaria, Acuícola y Forestal del Estado de México (ICAMEX), Gobierno del Estado de México, grant 2389/2006E and CONACYT-Mexico. Their support is thoughtfully acknowledged. 


\section{REFERENCES}

AFRC. Energy and protein requirements of ruminants. Wallingford: CAB International, 1993. p.159.

AOAC (Association off Analytic Chemists). Official method of analysis. 15.ed. Arlington, VA, 1990. Chap. 4. p. 1-73.

BONDI, A.A. Animal nutrition. Great Britain: John Wiley \& Sons, 1987. 687p.

CHESSON, A. Nutritional significance and nutrient value of plant polysaccharides. In: WISEMAN, J.; COLE, D.J.A. Feedstuff evaluation. London: Butterworths, 1990. p.179-195.

FRANCE, J. et al. A model to interpret gas accumulation profiles associated with in vitro degradation of ruminant feeds. Journal of Theoretical Biology, v.163, p.99-111, 1993. Available from:<http://www.sciencedirect.com/science/article/pii/ S0022519383711094>. doi:10.1006/jtbi.1993.1109.

GETACHEW, G. et al. Relationships between chemical composition, dry matter degradation and in vitro gas production of several ruminant feeds. Animal Feed Science and Technology, v.111, p.57-71, 2004. Available from: <http:// www.sciencedirect.com/science/article/pi i/ S0377840103002177>.

GRANT, A.S. Sward components. In: HODGSON, J. et al. Sward measurement handbook. Maidenhead: British Grassland Society, 1981. p.71-93.

HETTA, M. Timothy and red clover as forage for dairy production. 2004. Thesis (PhD) - Swedish University of Agricultural Sciences. p 42. Available from: <http:// pub.epsilon.slu.se/536/1/PDF_manus_Agraria_460.pdf $>$.

JUAREZ, R.S.A. et al. Estimación del valor nutricional de pastos tropicales a partir de análisis convencionales y de la producción de gas in vitro. Técnica Pecuária em México, v.47, p.55-67, 2009. Available from: <http://redalyc.uaemex.mx/src/inicio/ ArtPdfRed.jsp?iCve=61312109004>.

JUNG, H.G.; DEETZ, D.A. Forage cell wall structure and digestibility. Madison: ASA-CSSA-SSA, 1993. p. 350.

MAURICIO, R.M. et al. A semi-automated in vitro gas production technique for ruminant feedstuff evaluation. Animal Feed Science and Technology, v.79, p.321-330, 1999. Available from:<http://www.ingentaconnect.com/content/els/03778401/ 1999/00000079/00000004/art00033>. doi: 10.1016/S03778401(99)00033-4.

MERTENS, D.R. Rate and extent of digestion. In: DIJKSTRA, J.et al. Quantitative aspects of ruminant digestion and metabolism. Wallingford: CAB International. 2005. Chap 2. p. 13-49.
MINITAB Version13. User's guide II: data analysis and quality tools. USA, 2000. p. 216.

MOULD, F.L. et al. Alternative methodologies - stretching the in vitro box. Animal Feed Science and Technology, v.123-124, p.501515, 2005. Available from: <http://www.journals.elsevierhealth.com/ periodicals/anifee/article/PIIS0377840105001665/abstract $>$. doi:10.1016/j.anifeedsci.2005.04.023.

MOULD, F.L. et al. Cumulative and rate of gas release profiles of pure carbohydrates fermented in vitro using the reading pressure technique. In: GAS PRODUCTION: FERMENTATION KINETICS FOR FEED EVALUATION AND TO ASSESS MICROBIAL ACTIVITY, 2000, Wageningen International Conference, Centre Wageningen, The Netherlands. Proceedings of the EAAP Satellite Symposium: British Society of Animal Science, 2000. p.27-28.

PALMER, M.J.A.et al. Interference of direct gas produced by grass silage fermentation acids in an in vitro gas production technique. Animal Feed Science and Technology, v.123-124, p.185-196, 2005. Available from: <http://www.sciencedirect.com/science/ article/pii/S037784010500194X>.

PELL, A.N; SCHOFIEL, D.P. Computerized monitoring of gas production to measure forage digestion in vitro. Journal of Dairy Science, v.76, p.1063-1073, 1993. Available from: <http:// www.sciencedirect.com/science/article/pii/S0022030293774354>. doi:10.3168/jds.S0022-0302(93)77435-4.

THEODOROU, M.K. et al. A simple gas production method using a pressure transducer to determine the fermentation kinetics of ruminant feeds. Animal Feed Science and Technology, v.48, p.185-197, 1994. Available from: <http://www.sciencedirect.com/ science/article/pii/0377840194901716>. doi:10.1016/03778401(94)90171-6.

VAN SOEST, P.J. et al. Methods for dietary fibre, neutral detergent fibre and nonstarch polysaccharides in relation to animal nutrition. Journal of Dairy Science, v.74, p.35833597, 1991. Available from: <http://www.sciencedirect.com/ science/article/pii/S0022030291785512>. doi:10.3168/ jds.S0022-0302(91)78551-2.

WALLACE, R.J. et al. Influence of supplementary fibrolytic enzymes on the fermentation of corn and grass silages by mixed ruminal microorganisms in vitro. Journal of Animal Science, v.79, p.1905-1916, 2001. Available from: <http://jas.fass.org/ content/79/7/1905.full.pdf+html>.

WILSON, J.R. et al. Temperature effects on anatomy and digestibility of leaf and stem of tropical and temperate forage species. Journal of Agricultural Science, v.39, p.31-48, 1991. 